J. Perinat. Med. 15 (1987) 345

\section{Dopaminergic regulation of fetal growth hormone (GH) secretion: study with maternal administration of bromocriptine}

\author{
Giuseppe Robuschi ${ }^{1}$, Mara Montermini ${ }^{1}$, Paolo Chiodera ${ }^{1}$, Eliana Gardini ${ }^{1}$, Mario \\ Salvi $^{1}$, Alessandro Alboni ${ }^{2}$, Elisabetta Borciani ${ }^{1}$, Angelo Gnudi ${ }^{1}$, and Elio Roti ${ }^{1}$ \\ ${ }^{1}$ Department of Endocrinology and Pathology, University of Parma Medical \\ School, Parma, Italy, ${ }^{2}$ Division of Obstetrics and Gynecology, C. Magati Hospital, \\ Scandiano, Italy
}

\section{Introduction}

In adult life, pituitary growth hormone $(\mathrm{GH})$ secretion is mainly controlled by the stimulatory action of growth hormone releasing hormone (GHRH) and by the inhibitory effect of somatostatin (SRIH). Besides that, other factors seem to be involved in the regulation of $\mathrm{GH}$ secretion. Noradrenaline, dopamine (DA) and serotonine have a stimulatory action on $\mathrm{GH}$ secretion. Activation of central nervous system (C. N. S.) cholinergic pathways enhances $\mathrm{GH}$ secretion and the administration of gabaergic compounds has a stimulatory effect on $\mathrm{GH}$ release. In rat, opioid peptides have been reported to stimulate GH secretion, and in man the administration of an analogue of metenkefaline (FK 33-084) was effective in increasing serum GH concentrations $[10$, $18]$.

The regulation of $\mathrm{GH}$ secretion during fetal life or in the perinatal period has been less extensively studied. In the term fetus, cord blood GH concentrations are elevated. This condition has been attributed to an immaturity of the hypothalamic mechanisms controlling $\mathrm{GH}$ release [6]. This interpretation seems to be supported by studies describing a paradoxical response of $\mathrm{GH}$ following the administration of different substances such as glucose [6], aminoacids [13], L-dopa [5], and thyrotropin releasing hormone (TRH) [15].

In contrast, the pattern of $\mathrm{GH}$ response to the administration of other compounds such as SRIH [16], arginine [12] and insulin [3], indicates that $\mathrm{GH}$ secretion is regulated by mechanisms similar to those present in the adult life.
In the present study we have evaluated the effect of the maternal administration of bromocriptine on fetal and maternal serum GH concentrations. In the adult, the administration of bromocriptine, a DA agonist drug, has been found to have a stimulatory effect on GH secretion [2].

\section{Materials and methods}

Eighty-seven normal, term pregnant women were studied at parturition with their informed consent. During labor 46 women, randomly selected, were orally administered with $5 \mathrm{mg}$ of bromocriptine, whereas 41 received a placebo. Records were kept detailing the time of bromocriptine or placebo ingestion and the time of parturition. Maternal and cord blood (CB) specimens were obtained at parturition time from all mothers and their neonates. Serum was separated by centrifugation from red cells and stored at $-20^{\circ} \mathrm{C}$ until assay. During labor and delivery no adverse effects were observed. The clinical course of neonates whose mothers were treated with bromocriptine was uneventful.

Serum GH concentration was measured in all MS and $C B$ samples, except few whose volume was not sufficient.

All samples, diluted $1: 4$ in phosphate buffer, were measured in duplicate in the same assay and in random order employing materials obtained by Biodata (Milan, Italy). In this assay the cross reactivity with human Placental Lactogen (hPL) is $0.1 \%$. 
For statistical evaluation, GH results in MS obtained before bromocriptine and placebo ingestion were assigned to two groups: basal treated and basal control. GH results in MS specimens obtained at parturition were assigned to two groups: treated and control. Each of these two groups was subdivided into 7 subgroups according to the interval of time elapsed between bromocriptine or placebo ingestion and parturition time. $\mathrm{GH}$ results of neonates whose mothers were treated with bromocriptine were assigned to one group, treated, subdivided in 7 subgroups depending upon the interval of time between drug assumption and parturition time.

Similarly was done for $\mathrm{GH}$ concentrations of neonates whose mothers were treated with placebo.

Statistical analysis was conducted using Student's $t$ test for unpaired samples and one way analysis of variance (ANOVA). All values are expressed as the mean $\pm \mathrm{SE}$.

\section{Results}

Serum GH concentration in maternal serum: Before treatment, serum $\mathrm{GH}$ concentration in pregnant women receiving bromocriptine and placebo was $4.1 \pm 0.1 \mathrm{ng} / \mathrm{ml}$ and $3.9 \pm 0.1 \mathrm{ng} / \mathrm{ml}$, respectively (t test, NS).

At parturition, in control subgroups serum $\mathrm{GH}$ concentration averaged between 3.6 and $4.7 \mathrm{ng} /$ ml. These values were not significantly different (ANOVA test) from those observed in mothers administered with bromocriptine. In these subjects, serum $\mathrm{GH}$ concentration fluctuated between 3.5 and $4.5 \mathrm{ng} / \mathrm{ml}$ (table I).

Serum GH concentration in cord blood: In CB samples of neonates whose mothers were treated with placebo, serum GH concentrations were not different (ANOVA test) from those measured in neonates whose mothers received bromocriptine (figure 1).

In both groups, control and treated, cord blood $\mathrm{GH}$ concentrations were significantly higher than the corresponding maternal values, $\mathrm{p}<0.001(\mathrm{t}$ test).

\section{Discussion}

The participation of the dopaminergic pathways in the control of $\mathrm{GH}$ release has been clearly documented in man [18]. It is well known that DA agonist drug administration induces an increase of serum $\mathrm{GH}$ concentration [10]. In healthy adult subjects bromocriptine administration induces a rapid increase of $\mathrm{GH}$ secretion whereas in acromegalic patients significantly lowers serum GH concentrations [2].

During the perinatal period the role of DA in the control of GH secretion has been poorly investigated.

Table I. Serum growth hormone (GH) concentrations at parturition in mothers treated with placebo and bromocriptine.

Subgroups

\begin{tabular}{|c|c|c|c|c|c|c|c|}
\hline $\begin{array}{l}\mathrm{GH}(\mathrm{ng} / \mathrm{ml}) \\
\text { Concentration }\end{array}$ & $\begin{array}{c}1 \\
0-30^{\mathrm{a}}\end{array}$ & $\stackrel{2}{30-60}$ & $\begin{array}{c}3 \\
60-90\end{array}$ & $\begin{array}{c}4 \\
90-120\end{array}$ & $\begin{array}{c}5 \\
120-180\end{array}$ & $\begin{array}{c}6 \\
180-240\end{array}$ & $\begin{array}{c}7 \\
240-300\end{array}$ \\
\hline Control & $4.7 \pm \frac{ \pm}{2^{c}} 0.4^{b}$ & $3.7 \pm 0.1$ & $3.7 \pm 0.2$ & $3.7 \pm 0.4$ & $3.8 \pm 0.4$ & $4.1 \pm 0.3$ & $\begin{array}{c}3.6 \\
1\end{array}$ \\
\hline Treated & $4.3 \pm 0.5$ & $4.0 \pm \frac{ \pm}{7} 0.3$ & $4.4 \pm \frac{1}{7} 0.4$ & $3.5 \pm 0.2$ & $3.5 \pm 0.2$ & $4.0 \pm \frac{ \pm}{6} 0.3$ & $4.5 \pm 0.6$ \\
\hline
\end{tabular}

a) The range of time (minutes) elapsed between placebo or bromocriptine administration and maternal blood sampling.

b) Mean \pm SE.

c) Number of subjects in each subgroup.

No significant difference was observed between serum GH concentration in placebo and bromocriptine treated mothers (ANOVA Test). 


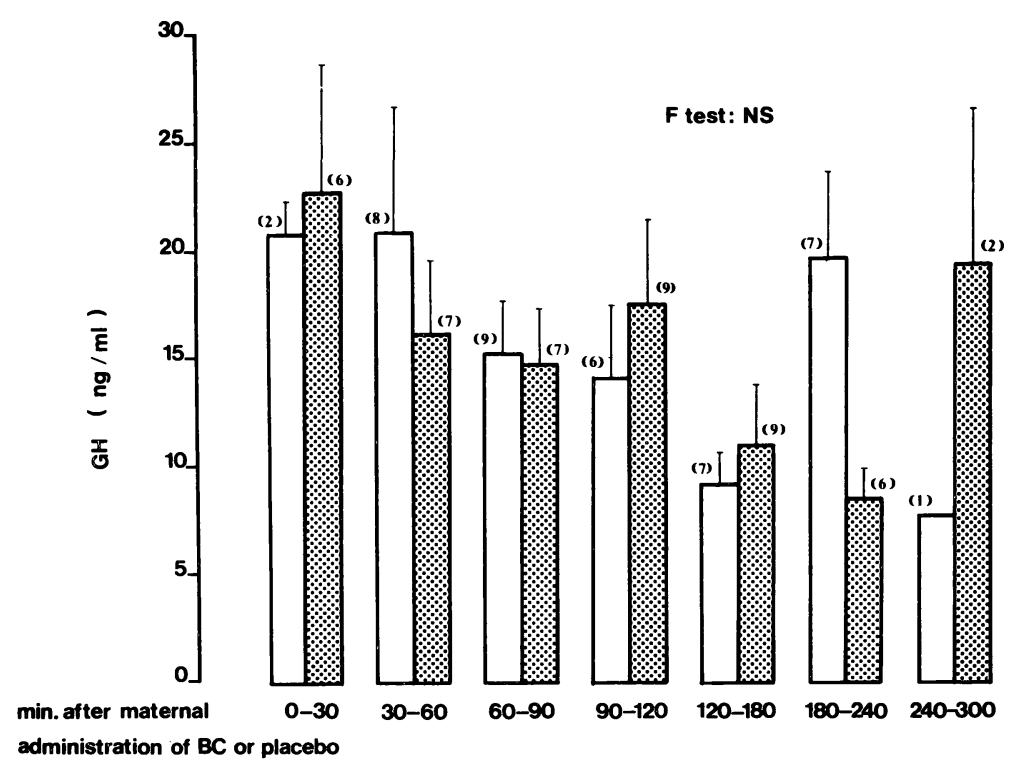

Figure 1. Cord blood (CB) GH concentration in neonates whose mothers received placebo ( ( $\square$ ) at different time periods after treatment. The bars represent the mean values and the brackets the SE. The numbers in parenthesis indicate the number of subjects in each group. No difference (ANOVA test) was observed in $\mathrm{CB}$ GH concentration between placebo and bromocriptine groups.

In the neonate, a paradoxical suppression of $\mathrm{GH}$ secretion has been observed after the administration of L-dopa [5]. In the ovine species, the administration of DA agonist drug induces a decrement of serum GH concentration both during adult [4] as well fetal and neonatal life [8].

In fetal and neonatal monkey, as in adult, the administration of L-dopa induces an increase of serum GH concentrations [6].

In the present study we have observed that the administration of bromocriptine to the mother does not induce any change of fetal serum $\mathrm{GH}$ concentrations. The lack of any effect of bromocriptine administration on fetal GH secretion does not seem to be related nor to an absent transfer of the drug through the placenta neither to an insufficient dose since we have observed that in newborns whose mothers received bromocriptine cord blood prolactin (PRL) concentrations were significantly lower than in newborns of control mothers [17].

Long term treatment with bromocriptine of an acromegalic patient througout pregnancy did not induce any change of fetal serum $\mathrm{GH}$ concentrations [1]. These findings are in agreement with the observation that maternal administration of metoclopramide, a dopaminergic receptor blocking drug, did not modify cord blood GH concentrations (RoTI, unpublished data).

Thus it is likely that the absent action of bromocriptine on fetal GH secretion might be due to a lack of activation of DA receptors at the hypothalamic and/or pituitary level.

The administration of bromocriptine, as well, did not induce any change in maternal serum $\mathrm{GH}$ concentrations. This finding has been previously reported in an acromegalic pregnant woman chronically treated with bromocriptine [1]. These results are in agreement with a previous observation from our laboratory [11] reporting that the administration of metoclopramide to parturient women did not induce any change of serum $\mathrm{GH}$ concentrations.

During late pregnancy, it has been reported an absent or blunted serum GH surge following secretory stimuli such as insulin induced hypoglycemia [9] and arginine infusion [21]. The increased serum concentrations of hPL [7], corticosteroids [4] and progestins [20] have been indicated as 
possible hormonal factors responsible for the absent $\mathrm{GH}$ response to insulin induced hypoglycemia.

Finally the hyperprolactinemic state both in maternal and fetal compartments might explain the absent GH response to bromocriptine. Recently it has been reported that in hyperprolactinemic women with pituitary microadenoma the administration of levo-DOPA and bromocriptine failed

\section{Summary}

To investigate the role of dopaminergic pathways on the control of growth hormone $(\mathrm{GH})$ secretion, bromocriptine (BMC), a dopamine agonist drug, was orally administered at the dose of $5 \mathrm{mg}$ to 46 pregnant women during labor whereas 41 received placebo. Maternal blood was obtained before drug administration and at delivery. Cord blood was obtained at delivery. Following the interval of time elapsed between BMC or placebo ingestion and parturition, maternal and cord blood sam-

Keywords: Bromocriptine, fetal growth hormone.

\section{Zusammenfassung}

Dopaminerge Regulation der fetalen WachstumshormonSekretion: Studie mit Verabreichung von Bromokriptin an die Mutter

Um die dopaminerge Wirkung auf die Sekretion des Wachstumshormons (STH) zu beurteilen, wurde 46 schwangeren Frauen $5 \mathrm{mg}$ Bromokriptin, ein dopaminerges Medikament, p. o. verabreicht, während weitere 41 Frauen mit Placebo behandelt wurden. Blutproben wurden vor der Verabreichung des Bromokriptin und zum Zeitpunkt der Geburt abgenommen. Proben aus der Nabelschnur wurden nach der Geburt gewonnen. Zur statistischen Beurteilung der Werte wurden die Proben aus dem mütterlichen und fetalen Blut in 7 Gruppen to stimulate $\mathrm{GH}$ secretion. This finding has been related to an impaired hypothalamic GHRH secretion or to decreased pituitary sensitivity to GHRH since L-Dopa and bromocriptine seem to act on GH release via GHRH [19].

In conclusion the present study suggests that in contrast to adult normal subjects bromocriptine administration does not enhance fetal and maternal serum $\mathrm{GH}$ levels.

ples were divided in 7 groups for statistical analysis. Cord blood GH resulted significantly higher than the corresponding maternal value $(p<0.001)$. No significant change in $\mathrm{GH}$ values was observed nor in samples of mothers treated with BMC compared to mothers treated with placebo neither in cord blood samples of the corresponding neonates. These findings indicate that BMC administration does not modify $\mathrm{GH}$ secretion in the term fetus.

Schlüsselwörter: Bromokriptin, fetales Wachstumshormon.

\section{Résumé}

Régulation dopaminergique de la sécrétion de l'hormone de croissance fotale: étude avec administration maternelle de bromocriptine

Afin d'explorer le rôle des voies dopaminergiques sur le contrôle de la sécrétion de l'hormone de croissance (GH), on a donné per os de la bromocriptine (BMC), médicament agoniste de la dopamine, à la dose de $5 \mathrm{mg}$, à 46 femmes enceintes, pendant le travail, tandis que 41 femmes prenaient un placebo. Du sang maternel a été prélevé avant la prise médicamenteuse et à l'accouchement. On a prélevé du sang au cordon lors de l'accouchement. En fonction de l'intervalle de temps qui s'est écoulé entre la prise de BMC ou du placebo et l'accou- unterteilt, und zwar je nach dem zeitlichen Intervall, das zwischen der Verabreichung des Medikamentes oder des Placebos und der Geburt lag. Das STH des Nabelschnurblutes ergab bei allen Neugeborenen eindeutig erhöhte Werte $(p<0,001)$ im Vergleich zum mütterlichen Blut. Bei einem Vergleich zwischen dem Blut von Müttern, die mit Bromokriptin, und solchen, die mit Placebo behandelt wurden, sowie bei Vergleichen des Nabelschnurblutes der entsprechenden Neugeborenen wurde kein signifikanter Unterschied bezüglich des STH festgestellt. Diese Ergebnisse deuten an, daß Bromokriptin die Sekretion des Wachstumshormons des reifen Neugeborenen nicht beeinflußt.

Mots-clés: Bromocriptine, hormone de croissance fœtale (GH).

chement, les prélévements sanguins maternels et du cordon ont été divisés en 7 groupes pour l'analyse statistique. Les résultats montrent que les valeurs de $\mathrm{GH}$ au sang du cordon étaient significativement plus élevées que les valeurs maternelles correspondantes $(p<0,001)$. On n'a pas observé de modifications significatives des valeurs de $\mathrm{GH}$ ni dans les prélévements de mères traitées par BMC en comparaison avec les mères avec placebo ni dans les prélévements au sang du cordon chez les nourrissons correspondants. Ces résultats indiquent que l'administration de BMC ne modifie pas la sécrétion de $\mathrm{GH}$ chez le fotus à terme. 
Acknowledgements: This work was supported in part by Grant N. 83.00471.04 of Consiglio Nazionale delle Ricerche, Rome, Italy. The authors express their deep gratitude to Mrs Marzia Mantovani for expert secretarial assistance.

\section{References}

[1] Bigazzi M, R Ronga, I Lancranjan, S Ferraro, F Branconi, P Buzzoni, G Martorana, GF SCARSelli, E Del Pozo: A pregnancy in a acromegalic woman during bromocriptine treatment: effects on growth hormone and prolactin in the maternal, fetal and amniotic compartments. J Clin Endocrinol Metab 48 (1979) 9

[2] Camanni F, F Massara, L Belforte, GM MoliNATTI: Changes in plasma growth hormone levels in normal and acromegalic subjects following administration of 2-bromo-alpha-ergocryptine. J Clin Endocrinol Metab 40 (1975) 363

[3] Cornblath M, MC Parker, SH Reisner, AE ForBES, WH DaughadaY: Secretion and metabolism of growth hormone in premature and full term infants. J Clin Endocrinol Metab 25 (1965) 209

[4] DAVIS SL, ML Borger: Hypothalamic catecholamine effects on plasma levels of prolactin and growth hormone in sheep. Endocrinology 92 (1973) 303

[5] Delitala G, T Meloni, a Masala, S alagna, L Devilla, R Costa: Action of somatostatin, levodopa and pyridoxine on growth hormone $(\mathrm{GH})$ secretion in newborn infants. Biomedicine 29 (1978) 43

[6] Gluckman PD, MM Grumbach, SL Kaplan: The neuroendocrine regulation and function of growth hormone and prolactin in the mammalian fetus. Endocr Rev 2 (1981) 363

[7] Kats HP, MM Grumbach, SL Kaplan: Diminished growth hormone response to arginine in puerperium. J Clin Endocrinol 29 (1969) 1414

[8] Marti-Henneberg C, PD Gluckman, R IsaAC, SL KAPLAN, MM GRUMBACH: Hormone ontogeny in the ovine fetus: XII. The dopaminergic regulation of growth hormone and chorionic somatomammotropin release. Endocrinology 109 (1981) 1355

[9] MinTz DH, R Stock, JL Finster, AL TAYLOR: The effect of normal and diabetic pregnancies on growth hormone responses to hypoglicemia. Metabolism 17 (1968) 54

[10] Morley JE: Neuroendocrine effects of endogenous opioid peptides in human subjects: a review. Psychoneuroendocrinology 8 (1983) 361

[11] Nakagawa K, Y Horiuchi, K Mashimo: Responses of plasma growth hormone and corticosteroids to insulin and arginine with or without prior administration of dexamethasone. J Clin Endocrinol 29 (1969) 35

[12] Reitano G, S Grasso, G Distefano, a Messina, G Palumbo, R VIGo: Regulation of insulin and GH secretion in the human fetus and newborn. In: Chiumello G, Z Laron (eds): Recent Progress in
Pediatric Endocrinology, p 37. Academic Press, London 1977

[13] Reitano G, G Distefano, R Vigo, L Gianta, S GRASSO: Effect of priming of aminoacids on insulin and growth hormone response in the premature infant. Diabetes 27 (1978) 334

[14] Robuschi G, R Emanuele, L d’Amato, M Salvi, M MONTERMINI, A GNUDI, E Roti: Failure of metoclopramide to release $\mathrm{GH}$ in pregnant women. Horm Metab Res 15 (1983) 460

[15] Roti E, A Gnudi, G Robuschi, R Emanuele, L BENASSI, LE BRAVERMAN: Response of growth hormone $(\mathrm{GH})$ to thyrotropin-releasing hormone (TRH) during fetal life. J Clin Endocrinol Metab 54 (1982) 1255

[16] Roti E, G Robuschi, A Alboni, R Emanuele, L D'Amato, E Gardini, M Salvi, E Dall'Aglio, A GNUDI, LE BRAVERMAN: Inhibition of foetal growth hormone $(\mathrm{GH})$ and thyrotropin (TSH) secretion after maternal administration of somatostatin. Acta Endocrinol (Copenh) 106 (1984) 393

[17] Roti E, G Robuschi, A Alboni, L d’Amato, M Montermini, E Gardini, M Salvi, E Borciani, E Dall'Aglio, S Bisi, G Zammarchi, P Lasagni, A GNUDI, LE BRAVERMAN: Human fetal prolactin but not TSH secretion is affected by dopaminergic stimuli. Acta Endocrinol (Copenh) 112 (1986) 35

[18] Scanlon MF, M Pourmand, AM McGregor, MD Rodriguez-Arnao, K Hall, A Gomez-Pan, R HALL: Some current aspects of clinical and experimental neuroendocrinology with particular reference to growth hormone, thyrotropin and prolactin. J Endocrinol Invest 2 (1979) 307

[19] SeKi K, K Kato, K Shima: Absence of growth hormone response to L-dopa and bromocriptine in hyperprolactinemic women with pituitary microadenoma. J Clin Endocrinol Metab 62 (1986) 783

[20] Simons S, M Schiffer, SM Glick, E Schwartz: Effect of medroxyprogesterone acetate upon stimulated release of growth hormone in men. J Clin Endocinol 27 (1967) 1633

[21] Tyson JE, D Rabinowitz, TJ MerimeE, H Friesen: Response of plasma insulin and growth hormone to arginine in pregnant and postpartum females. Am J Obstet Gynecol 103 (1969) 313

Received March 17, 1986. Revised November 14, 1986. Accepted December 23, 1986.

Dr. Elio Roti

Cattedra di Endocrinologia

e Patologia Costituzionale

Via Gramsci 14

43100 Parma, Italy 